\title{
Fast and Inexpensive self-made Tissue Microarray for Immunohistochemical and in Situ Hybridization Studies: Examples with Bladder Cancer
}

\author{
Selim Komina* and Gordana Petrusevska \\ Institute of Pathology, Medical Faculty, Ss. Cyril and Methodius University, Skopje, R . Macedonia
}

\section{ABSTRACT}

Background: The tissue microarray (TMA), first described by Battifora and first implemented in 1998 by Kononen et al, is a powerful research tool, allowing simultaneous analysis of specimens from a large number of cases on one slide. Unfortunately, commercial aray instruments are very expensive and thus not suitable for laboratories with limited funds. We describe simple and cost-effective method for constructing of manual TMA that can be performed by any anatomic pathology laboratory, requiring minimum skill and time.

Methods: Skin punch biopsy needle of 2-mm diameter was used for extracting cores from 15 positive control breast cancer cases, 15 normal bladder tissue and 30 muscle-invasive bladder cancer and for injecting into recipient block.

Result: We constructed TMA block using skin punch biopsy needle of 2-mm, and succesfulfully performed HER2 immunodetection and Chromogenic In Situ Hybridization study, without substantial tissue loss. 10\% of our tumor cases exhibited Her-2 neu overexpression. An open source software programme "TMA-J" was applied to facilitate management, viewing, analysis of tissue microarray images and associated clinico-pathology data.

Conclusion: This method could be done by any pathology laboratory and represents good and reliable alternative for commercially available, expensive devices and software solutions.

Keywords: Tissue Microarray, HER-2 Chromogen in Situ Hybridization, Bladder Cancer

\section{Introduction}

The tissue microarray (TMA), first described by Battifora $^{[1]}$ and first implemented in 1998 by Kononen et al. ${ }^{[2]}$, is a powerful research tool, allowing simultaneous analysis of specimens from a large number of cases on one slide ${ }^{[3]}$, thus reducing the use of reagent, time and human resources. It can also be used to study protein markers by immunohistochemistry and to investigate DNA aberrations, messenger RNA and micro RNA expression using in situ hybridization techniques ${ }^{[4-6]}$, Furthermore, TMA provide uniform experimental conditions to the tissue samples analyzed. ${ }^{[7]}$ Other researchers have adapted TMA technology in the study of frozen tissues, cell lines, and needle biopsies. ${ }^{[8]}$

The TMA manufacturing is a simple three step procedure that is repeated for each sample placed on the TMA:

1. Making a hole in an empty (recipient) paraffin block.

2. Taking a cylindrical sample from the tissue sample (donor) paraffin block.

3. Placing the cylindrical tissue sample in the premade hole in the recipient block.
Unfortunately, commercial aray instruments are very expensive and thus not suitable for laboratories with limited funds.

We describe simple and cost-effective method for constructing of manual TMA that can be performed by any anatomic Pathology Laboratory, requiring minimum skill and time.

\section{Materials and Methods}

Skin punch biopsy needle of 2-mm diameter was used for extracting cores from 15 positive control breast cancer cases, 15 normal bladder tissue and 30 muscle-invasive bladder cancer and for injecting into recipient block.

A recipient block was prepared by using modified metal mold, enabling maximal dimensions of $43 \times 27 \times 11 \mathrm{~mm}$ to fit the microtome block holder. (Fig 1a) After paraffin puring, the block was cooled at room temperature to avoid cracks. (Fig. 1b) Before drilling, the recipient block was examined for air bubbles and paraffin cracks. We designed a grid using the drawing software Corel Draw ${ }^{\circledR}: 2 \mathrm{~mm}$ white circles were drawn and alligned at a distance of $1,5 \mathrm{~mm}$, on a colorful background; the grid was printed on plain paper. 
The adhesive dot-grid paper was attached to the surface of the bare paraffin block, (Fig. 1c,d ) leaving 2,5-3mm space from the margin and used as a guide to make array pores into the recipient block. (Fig.1e ) Sample tissue cores were then inserted into the appropriate holes on the recipient block at defined array coordinates. (Fig.1f,g)

A modified metal wire was used as a stylet to remove sample tissue cores from dermal biopsy punch needle.( Fig.1h) The recipient block (Fig. 1i) was put in an oven at about 59C for 30 minutes with cutting surface faced down on a glass slide. (Fig.1j) The tissue array was sectioned at 5 microns using a standard microtome (Fig. 1k) and used for Hematoxylin-eosin staining, HER2 immunodetection and Chromogenic In Situ Hybridization, following the standard manual procedures. (Fig.11)
The H\&E images, Immunohistochemical and Chromogenic In Situ images of the tissue cores were captured in digital format (Bresser MicroCam Lab II) and subsequently analyzed. (Fig. 2) An open source software programme “TMA-J' was applied to facilitate management, viewing, analysis of tissue microarray images and associated clinico-pathology data. (Fig. 3).

\section{Result}

We constructed TMA block using skin punch biopsy needle of 2-mm diameter containing 15 positive control breast cancer cases, 15 normal bladder tissue and 30 muscleinvasive bladder cancer specimens, and successfully performed HER2 immunodetection and Chromogenic in situ hybridization study, without substantial tissue loss.

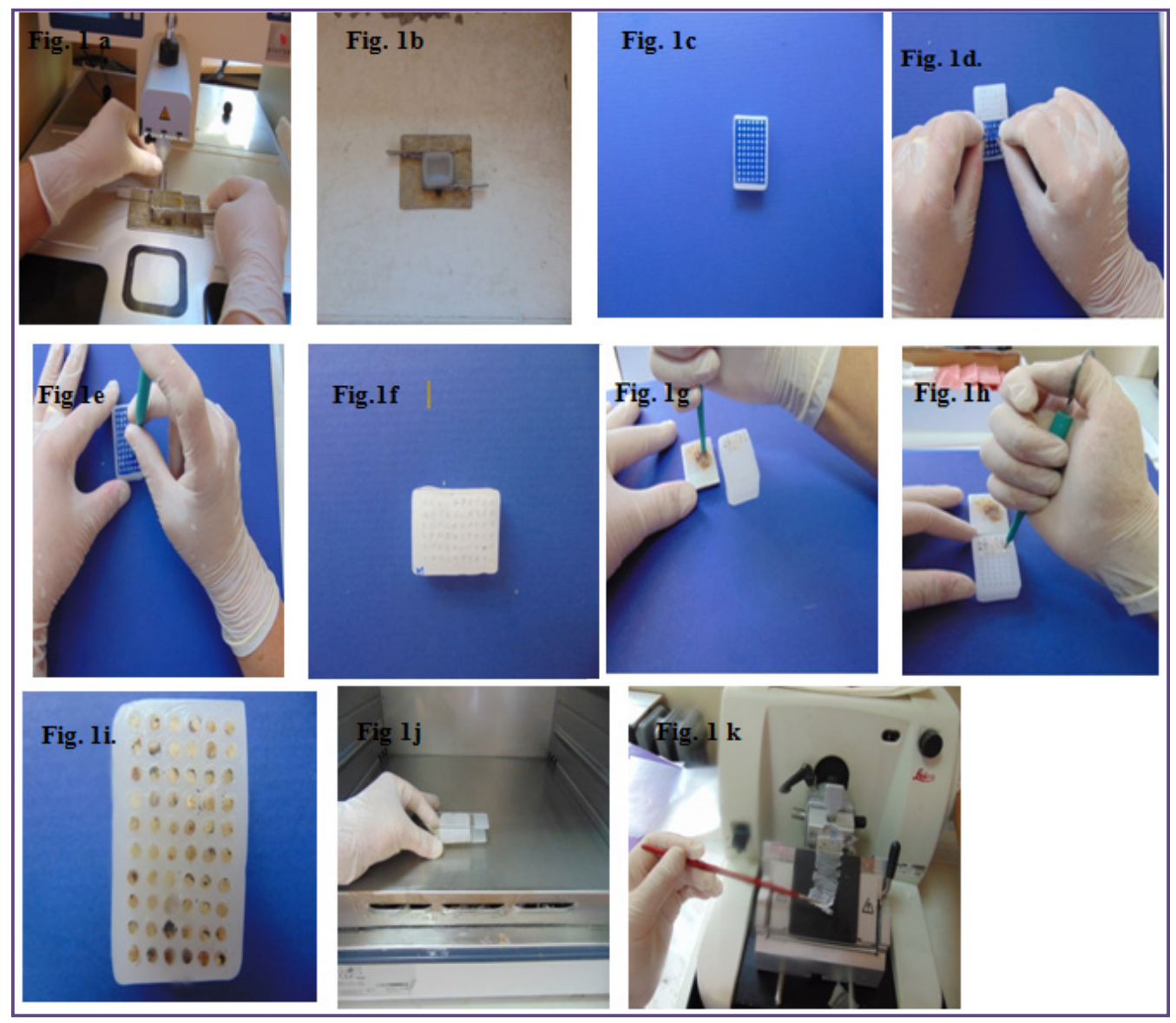

Fig. 1: Manual construction of tissue microarray (TMA) with $2 \mathrm{~mm}$ core diameter. Modified metal mould was used for preparing recipient block with maximal dimensions of $43 \times 27 \times 11 \mathrm{~mm}$ to fit the microtome block holder (a). Melted paraffin was gently pured on the mould and lefted to be cooled at room temperature (b). To guide the boring of holes, pre-designed adhesive dot- grid paper using Corel Draw $®$ software , was attached to the surface of bare paraffin block, leaving 2,5-3 mm space from the margin (c). After completion of boring (d), the dot-grid paper was removed (e, f) and tissue cores from the donor blocks (g) were transferred into the holes $(\mathrm{h})$ using a dermal biopsy punch needle and a modified metal wire to make a TMA containing 60 tissue cores (i). The recipient block was put in an oven at about 59C for 30 minutes with cutting surface faced down on a glass slide $(j)$ and cut at 5 microns. (k). 


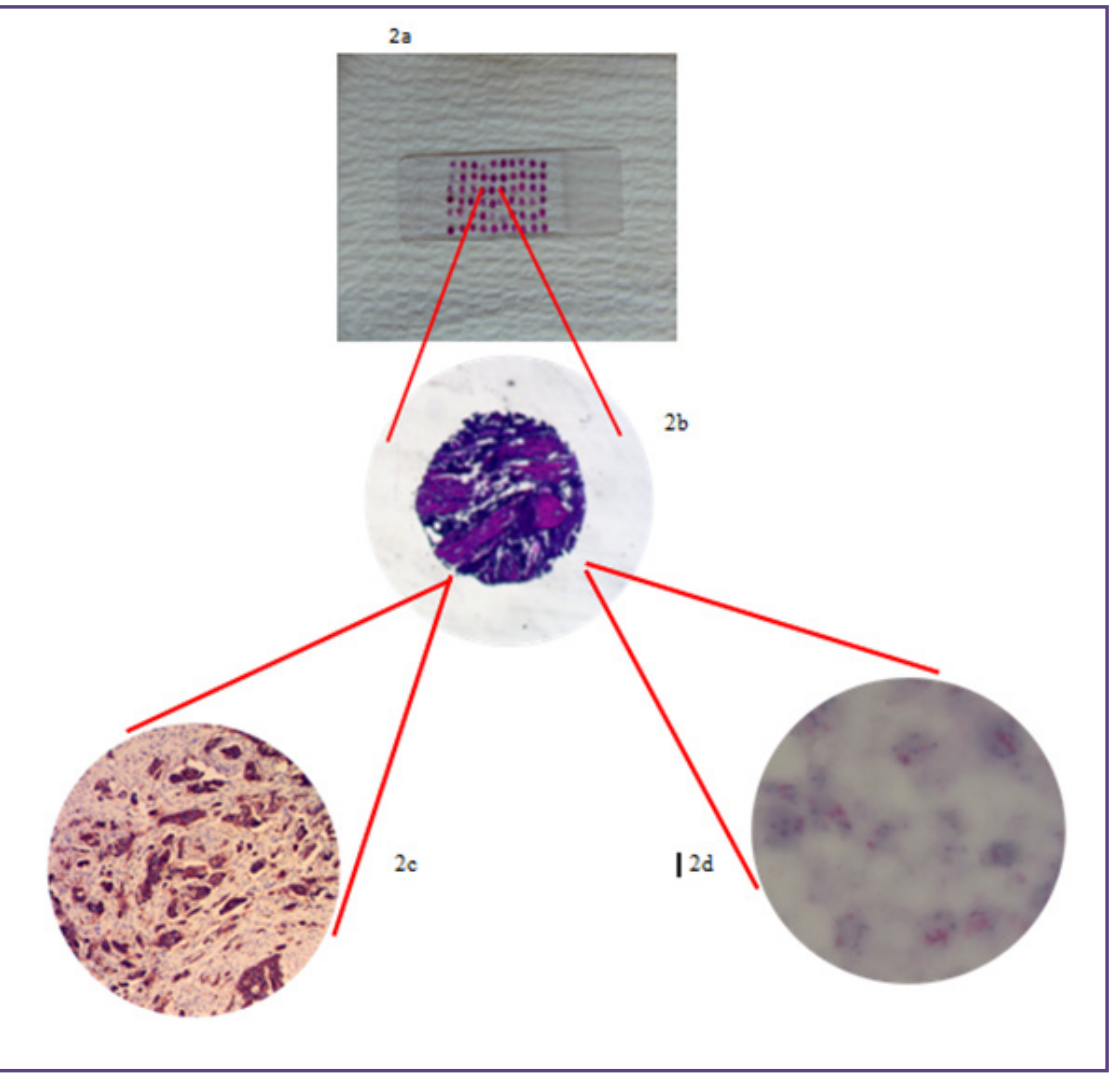

Fig. 2: H\&E slide with 60 tissue cores (a), Hematoxylin-eosin (H\&E) stained slides (b (x40), Strong and diffuse HER2 immunostaining surrounding the entire cell membrane (score 3+) (c, x 100) and Chromogenic in situ amplification in a sample scored 2+ with 3+ score area. ( $\mathrm{d} x$ 400).

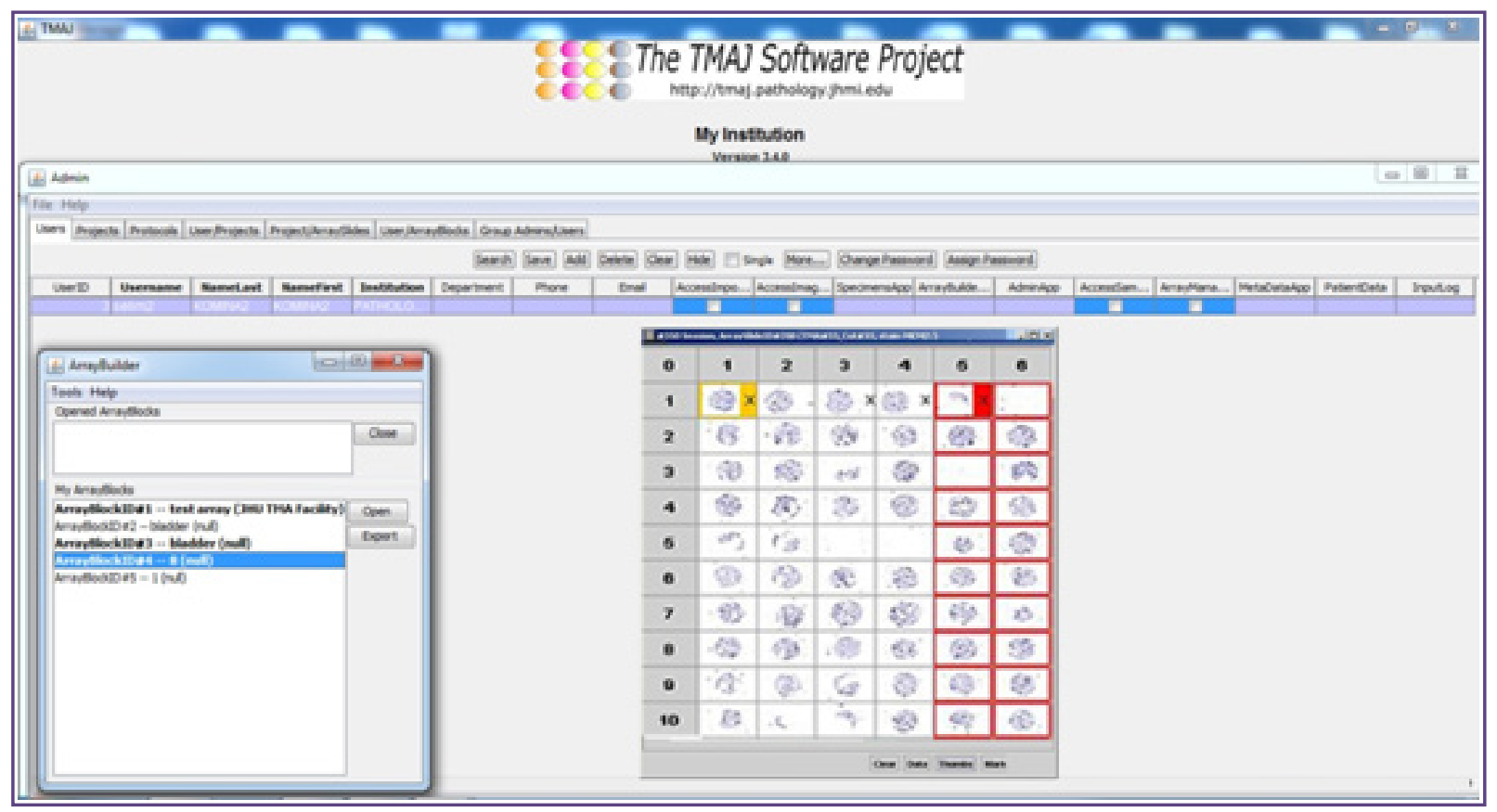

Fig. 3: Web interface of the TMAJ Software Project. 
Table 1. Overview of simple and inexpensive methods for manual construction of TMAs

\begin{tabular}{|c|c|c|c|c|c|c|}
\hline $\begin{array}{l}\text { Preparation of } \\
\text { recipient block/Array } \\
\text { methods }\end{array}$ & $\begin{array}{l}\text { Extraction of } \\
\text { paraffin tissue } \\
\text { cores from } \\
\text { donor block }\end{array}$ & $\begin{array}{l}\text { Capacity of } \\
\text { TMA block }\end{array}$ & $\begin{array}{l}\text { Time required } \\
\text { for TMA } \\
\text { construction }\end{array}$ & $\begin{array}{l}\text { Spot loss } \\
\text { on TMA } \\
\text { section (\%) }\end{array}$ & $\begin{array}{l}\text { Initial cost } \\
(\$)\end{array}$ & References \\
\hline $\begin{array}{l}\text { Boring holes in bare } \\
\text { paraffin blocks using } \\
\text { mechanical pencil tip }\end{array}$ & $\begin{array}{l}\text { Mechanical } \\
\text { pencil tip }\end{array}$ & $\begin{array}{l}1 \mathrm{~mm}, 72 \\
(9 \times 8)\end{array}$ & $1 \mathrm{hr}$ & 2 & $<5$ USD & Shebl et al. ${ }^{[12]}$ \\
\hline $\begin{array}{l}\text { No recipient block } \\
\text { (alignment of tissue } \\
\text { cores on hand-made } \\
\text { paper mold }\end{array}$ & $\begin{array}{l}\text { BM biopsy } \\
\text { needle }\end{array}$ & $\begin{array}{l}2 \mathrm{~mm}, 40 \\
(8 \times 5)\end{array}$ & Not-specified & No & Cost neglible & Wang et al. ${ }^{[13]}$ \\
\hline $\begin{array}{l}\text { No recipient (alignment } \\
\text { of tissue cores on the } \\
\text { bottom of mold with a } \\
\text { thin layer of soft wax) }\end{array}$ & $\begin{array}{l}\text { BM biopsy } \\
\text { needle }\end{array}$ & $\begin{array}{l}2 \mathrm{~mm}, 88 \\
(11 \times 8)\end{array}$ & Not-specified & $<2$ & Cost neglible & Pan et al..$^{[14]}$ \\
\hline $\begin{array}{l}\text { Boring holes in bare } \\
\text { parafin block using } \\
\text { needle or small } \\
\text { screwdriver }\end{array}$ & $\begin{array}{l}\text { BM biopsy } \\
\text { needle }\end{array}$ & $\begin{array}{l}1 \mathrm{~mm}, 56 \\
(8 \times 7) \\
1 \mathrm{~mm}, 108 \\
(12 \times 9) \\
2 \mathrm{~mm}, 77 \\
(11 \times 7)\end{array}$ & $1 \mathrm{hr}$ for 56 cores & $<1$ & 30 USD & Singh et al. , ${ }^{[15]}$ \\
\hline $\begin{array}{l}\text { No recipient block } \\
\text { (alignment of tissue cores } \\
\text { in the dot-grid paper } \\
\text { attached to the bottom of } \\
\text { microcompound table }\end{array}$ & $\begin{array}{l}\text { Hypodermic } \\
\text { needle with } \\
\text { lateral opening, } \\
\text { attached to } \\
\text { hand-press } \\
\text { grommet insert } \\
\text { machine }\end{array}$ & $\begin{array}{l}0,6 \mathrm{~mm}, \\
325(25 \times 13)\end{array}$ & $7,5 \mathrm{hr}$ & $<1$ & 100 USD & $\begin{array}{l}\text { Pathak et al. } \\
\text { [16] }\end{array}$ \\
\hline $\begin{array}{l}\text { Boring holes in bare } \\
\text { paraffin block using } \\
\text { mini hand drill and } \\
\text { microcompound table }\end{array}$ & $\begin{array}{l}\text { Hypodermic } \\
\text { needle, cannula } \\
\text { piercing needle, } \\
\text { BM biopsy } \\
\text { needle, skin } \\
\text { biopsy punch, } \\
\text { equipped with } \\
\text { retracta-ble } \\
\text { stylet }\end{array}$ & $\begin{array}{l}0,6 \mathrm{~mm} \\
558(31 \times 18) \\
0,43 \mathrm{~mm} \\
1,363(47 \mathrm{x} \\
25)\end{array}$ & $\begin{array}{l}\text { Not specified } \\
6 \mathrm{hr}\end{array}$ & 30 & 300 USD & $\begin{array}{l}\text { Nocito et al. }{ }^{[17]} \\
\text { Vogel }{ }^{[18]}\end{array}$ \\
\hline $\begin{array}{l}\text { Boring holes guided by } \\
\text { dot-grid paper directly } \\
\text { attached to the bare } \\
\text { paraffin block }\end{array}$ & $\begin{array}{l}\text { Cannula } \\
\text { piercing needle, } \\
\text { BM biopsy } \\
\text { needle, skin } \\
\text { biopsy punch, } \\
\text { equipped with } \\
\text { retractable } \\
\text { stylet }\end{array}$ & $\begin{array}{l}0,6 \mathrm{~mm}, \\
320(16 \times 20) \\
1 \mathrm{~mm}, 140 \\
(14 \times 10) \\
1,8 \mathrm{~mm} / 2 \\
\mathrm{~mm}, 70 \\
(10 \times 7)\end{array}$ & $\begin{array}{l}6 \mathrm{hr} \\
3 \mathrm{hr} \\
1,5 \mathrm{hr}\end{array}$ & $\begin{array}{l}2-3 \\
1-2 \\
\text { Rare }\end{array}$ & Cost neglible & Choi et al. ${ }^{[19]}$ \\
\hline
\end{tabular}

HER2 evaluation, according to ASCO-CAP HER2 Test Guideline Recommendations for breast cancer,[9] revealed overexpression in $10 \%$ of tumor samples which is in concordance with results reported by Lae et al,[10] who has documented an incidence of $9,2 \%$ in a series of 1005 cases. An open source software tool was implemented for automated preprocessing, organization, storage, and display of TMA images.

\section{Discussion}

The TMA is one of the essential tools used in biomedical research techniques such as immunohistochemistry, in situ hybridization, and in situ reverse transcription 
polymerase chain reaction. ${ }^{[11]}$ On the other hand, the high cost of array machines of several thousands dollars or, even a manual tissue array system that costs several hundred dollars, are a strong deterrent to its routine use in institutions with limited budgets.

Several publications have reported alternative, low - cost , methods for array construction. (Table 1). ${ }^{[12-19]}$ However, in most of cases, the development of these tecnhniques is related to personal laboratory technicians' skillfulness or require of specialized instruments, making the production of TMAs more laborious. Author's objective was to overcome this problem by offering both an inexpensive and flexible method that could be modified according to the requirements of the lab, with respect to the number of cores in one block. The whole array set we used had a total price of 5 USD. When compared to commercial machines, the authors acknowledge the significant lower number of maximal tissue cores in the recipient block and the bigger timeframe of about 10 minutes needed to construct the array. One possible solution for increasing the tissue core density is using $1 \mathrm{~mm}$ or $1,5 \mathrm{~mm}$ skin biopsy punch needles. Conversely, they are regarded as of inconsiderable importance compared to the advantages that it offers when finances are important concerns.

Futhermore, differing from those that have been described in the literature, we provide 'open- source' free software solutions available over the Internet for academic use. This still requires an image- capturing system to create an archived database of images for further analysis. In the first of these, an open-source java-based software called "TMAJ" is available from the website of the John Hopkins University TMA core facility (http:// tmaj.pathology. jhmi.edu/). A licence is however, required for users with potential commercial interests.

Another noteworthy database for TMA analysis has been described using TAMEE: data management and analysis for tissue microarrays available at http://genome.tugraz.at/ Software/TAMEE.

For managing high-density TMAs, the "Cluster" and "TreeView" software tools, developed at Standford university, analyze the relatedness within tumor subsets depending on the immunohistochemical biomarker profile. Free access is possible at the Standford TMA website (http://genome-www.standfors.edu/TMA), two other software programs are available at the website of Michaen B. Eisen' lab (http: //rana. lbl.gov/EisenSoftware.htm).

\section{Conclusion}

We successfully performed, HER2 neu immunohistochemical and Chromogenic In Situ Hybridization studies on a self-made tissue microarray, without any substantial tissue loss. $10 \%$ of tumor cases exhibited HER2 overexpression. An open source software tool was implemented for automated preprocessing, organization, storage, and display of TMA images. This method could be done by any pathology laboratory and represents good and reliable alternative for commercially available, expensive devices and software solutions.

\section{Reference}

1. Battifora H. The multitumor (sausage) tissue block: novel method for immunohistochemical antibody testing.Lab Invest. 1986;55:244-248.

2. Kononen J, Bubendorf L, Kallioniemi A. Tissue microarrays for high-throughput molecular profiling of tumor specimens. Nat Med. 1998;4:844-47.

3. Wang H, Wang H, Zhang W, Fuller GN. Tissue microarrays: applications in neuropathology research, diagnosis, and education. Brain Pathol. 2002;12(1):95-107.

4. Bordeaux, J.M.; Cheng, H.; Welsh, A.W.; Haffty, B.G.; Lannin, D.R.; Wu, X.; Su, N.; Ma, X.J.; Luo, Y.; Rimm, D.L. Quantitative in situ measurement of estrogen receptor mRNA predicts response to tamoxifen. PLoS ONE 2012, 7, e36559.

5. Francis, GD, Jones MA, Beadle GF, Stein SR. Bright-field in situ hybridization for HER2 gene amplification in breast cancer using tissue microarrays: Correlation between chromogenic (CISH) and automated silver-enhanced (SISH) methods with patient outcome. Diagn. Mol. Pathol. 2009;18: 88-95.

6. Zlobec, I.; Terracciano, L.; Tornillo, L.; Gunthert, U.; Vuong, T.; Jass, J.R.; Lugli, A. Role of RHAMM within the hierarchy of well-established prognostic factors in colorectal cancer. Gut 2008, 57, 1413-1419.

7. Cheng, H.; Ballman, K.; Vassilakopoulou, M.; et al. EGFR expression is associated with decreased benefit from trastuzumab in the NCCTG N9831 (Alliance) trial. Br. J. Cancer 2014; 111:1065-1071

8. Schoenberg Fejzo M, Slamon DJ : Frozen tumor tissue microarray technology for analysis of tumor RNA, DNA, and proteins. Am J Pathol 159: 1645-1650,2001.

9. http://www.cap.org/apps/docs/committees/ immunohistochemistry/summary_of_recommendations.pdf

10. Laé M, Couturier J, Oudard S, Radvanyi F, Beuzeboc P, Vieillefond A. Assessing HER2 gene amplification as a potential target for therapy in invasive urothelial bladder cancer with a standardized methodology: results in 1005 patients. Annals of Oncology. 2010;21: 815-819

11. Datta MW, Kahler A, Macias V, Brodzeller T, KajdacsyBalla A: A simple inexpensive method for the production of tissue microarrays from needle biopsy specimens: Examples with prostate cancer. Appl Immunohistochem Mol Morphol 2005;13: 96-103. 
12. Shebl AM, Zalata KR, Amin MM, El-Hawary AK. An inexpensive method of small paraffin tissue microarrays using mechanical pencil tips. Diagn Pathol. 2011; 6:117

13. Wang SL, Yang $\mathrm{CH}$, Chen $\mathrm{HH}$, Chai CY. A simple and economical method for the manual construction of well-aligned tissue arrays. Pathol Res Pract. 2006; 202:485-486.

14. Pan CC, Chen PC, Chiang H. An easy method for manual construction of high-density tissue arrays. Appl Immunohistochem Mol Morphol. 2004; 12:370-372

15. Singh DK, Sakhuja P, Gondal R. Making and using inexpensive manually constructed tissue micro-array: experience of a tertiary care hospital in India. Indian J Pathol Microbiol. 2009; 52:304-309.
16. Pathak GS, Deshmukh SD, Ashturkar AV. Construction of tissue arrays without prefabricated recipient paraffin block experience of a novel technique in resource poor settings. Indian J Pathol Microbiol. 2011; 54:654-655.

17. Nocito A, Kononen J, Kallioniemi OP, Sauter G. Tissue microarrays (TMAs) for high-throughput molecular pathology research. Int J Cancer. 2001; 94:1-5.

18. Vogel UF, Bueltmann BD. Simple, inexpensive, and precise paraffin tissue microarrays constructed with a conventional microcompound table and a drill grinder. Am J Clin Pathol. 2006; 126:342-348.

19. Choi CH, Kim KH, Song JY, et al. Construction of HighDensity Tissue Microarrays at Low Cost by Using SelfMade Manual Microarray Kits and Recipient Paraffin Blocks. Korean Journal of Pathology 2012; 46(6): 562-568.

*Corresponding author:

Selim Komina, 50ta Divizija 6, Skopje, R. Macedonia

Phone: +0038970807210

Email: s_komina@yahoo.com

Date of Submission : 15.11.2016

Date of Acceptance : 10.12.2016

Financial or other Competing Interests: None.
Date of Publication : 23.02.2017 